\title{
The Explication of Margaret Drabble's Feminist Ideas Against the Background of the Confrontation of Two Thinking Models (on the basis of the novel "The Millstone")
}

\author{
Azıza Sahıb Salamova \\ Azerbaijan University of Languages
}

\begin{abstract}
The works of Margaret Drabble, who is considered one of the outstanding representatives of contemporary British feminist, is appraised as the manifesto of the feminist ideas. In her works M.Drabble addresses the problems of the society she lives in through her own identity and guides her creative identity to writing novels that urge one to think and make a choice. The writer has succeeded in presenting the ideas of feminism from the standpoint of "gender simmetry" and raised the problems of women and society, women and community. M.Drabble formulates her protest against the discrimination between woman and man by appealing to the restriction of female freedom. Her characters are courageous women who can act as a role-model in women's struggle for choice - to live the life they want and decide on their own life. As a woman, spouse, mother, working woman, M.Drabble clearly realizes the impact of the burden laden on "the weaker gender" in all stages of women's life and the stereotypes of behaviour dictated by social dominance and manages to act as "the mediator" for women, first of all, herself and her contemporaries by observing the complications led by the gender asymmetry. The heroine of the novel "Millstone" is the manifestation of the writer's visions and the description of her confidence in a modern woman. M.Drabble manages to describe the image of a modern woman in the most convincing details and in full accuracy by coming round her heroine's life out of her own. The analysis of M.Drabble's novel "Millstone" brings to the reader's judgement most austerely and boldly the two confrontations peculiar to her works. The problem raised in the work consists of the confrontation of the woman's motherhood and spousehood which almost make "the neat line" of Drabble's novels. The novel "Millstone" reveals most vividly the ideational-philosophical reality formed resulting from the XX-century feminist ideas, the women's discarding their aspiration towards marriage as the number one indicator of their life success as "the aftereffects" of the alienation trends of gender stereotypes. This work is the successful solution from the perspective of describing the difficult path of a modern British woman's recognition of her real power and realization of her psycho-social identity quite adequetely.
\end{abstract}

The key words: British feminist, Margaret Drabble, feminism, choice and the problem of the lack of choice

\section{INTRODUCTION}

It wouldn't be so wrong if we appraise the works of Margaret Drabble, who is considered one of the outstanding representatives of contemporary British feminist, as the manifestato of the feminist ideas at many points. M.Drabble is considered one of the "most feminist" authors of contemporary British literature owing to her skill of "feeling the pulse" of the problems disturbing contemporary British society, especially describing in unbiased and objective manners the challenges faced by women in their social groups as well as her success in acting as a mediator for women's most intimate wishes and desires. In this sense, one cannot but agree with Phyllis Rose's appraisal, "She is one of the most interesting novelists in England today, and her career is arguably the most important of all. For she is becoming the chronicler 
of contemporary Britain, the novelist people will turn to a hundred years from now to find out how things were, the person who will have done for late-20th-century London what Dickens did for Victorian London, what Balzac did for Paris. (Ismailova 2015, p.15). Actually, "the chronicler of contemporary Britain" M.Drabble, who could be considered the most feminist writer of contemporary British literature, is not only "the chronicler" with an approach she introduced in her works, but also has turned her creative identity, which settles in the centre of events, in the epicenter of processes, evaluates each problem by the standards of personal identity and enjoys the civic stand, into one of the prestigious figures in modern British society. M.Drabble is not simply a writer, but also a factor of social thinking that vividly demonstrates the social "anamnesis", psycho-emotional complications of the most vulnerable problem of the community with a range of problems she raises in her works and urges the reader (thus, the member of the community) to think and make a choice. Undoubtedly, the role and stand of a woman in contemporary British society, her rights and freedoms differ fundamentally from the situation half a century ago, that is from the period when M.Drabble made her first steps in her creative activity. If we premise on the undeniable fact that the feminist ideas already showed their positive sprouts in British society, we wouldn't be wrong to point out also M.Drabble's special role in this state of more successful "gender symmetry". In her famous manifestoarticle "The Sexual Revolution" written in 1967 M.Drabble elucidates her ideas about the emancipation process as follows, "This freedom is evidently connected to that other major revolution of our society, the emancipation for women. It is the final clause in the contract, the clinching argument. Education, freedom to work, equal pay and social equality did not mean much when they could be negated by the arrival of one small unintended baby.

\section{SCOPE OF STUDY}

The characters of M.Drabble, who focus attention on the difference of the requirements of social dominance for women and men, more restrictions to women's freedoms from the perspective of stereotyping approaches, do not hesitate to express their protests against any forms of gender asymmetry. As Jane Flax notes, actually, "The persistence of such gender asymmetries generates vigorous feminist debate. Some argue discourses of equality replicate rather than undermine male dominance. The male side of the gender binary remains the norm, hence female difference is devalued. Equality simply means the integration of women within "male-ordered" states. Insofar as individual women seek to emulate male-dominant values, they may attain equal access to political, cultural, and economic institutions" (Phyllis 2004, p. 66). In this sense, the initial stage of the radical solution to the "women's problem" in society can start with the decision of the community on the reformation of that asymmetry. Any other interventions can be considered correction-like amendments, whereas M.Drabble quite vividly exposes such an approach as a radical mistake through her characters' life stand. Drabble characters are determined in their struggle not for the reformation of the woman's definite social, material and moral problems, but for the delivery of women's rights and freedoms to a decent level as a whole. Her characters are courageous women who can act as a role-model in the struggle for women's choice - to live the life they want and decide on their own life. Actually, through the voices of her heroines the author presents her own search for an answer to many questions bothering her long. While some questions are answered, some issues are still expecting their straightforward solution in M.Drabble's works.

\section{ANALYSES}

Suhasini Tapaswi is right to state, “... a whole generation of woman readers identies with her characters who they feel represent their own problems. Her heroines are pre-occupied with the difficulties of fulfilment and self-definition in man's world, conflicting claims of self-hood, wife-hood and mother-hood (Atalla Diyaie 2015, p.13). In other words, as a woman, spouse, 
mother, working woman, M.Drabble clearly realizes the impact of the burden laden on "the weaker gender" in all hypostases of women's life and the stereotypes of behaviour dictated by social dominance and cognitive schemes, and succeeds in acting as "the mediator" for women, first of all, herself and her contemporaries by observing the complications led by the gender asymmetry. Thus, it is due to it, that is, “because of a whole generation of women's identification of themselves with M.Drabble's heroines that A.A.Blagoveshenskaya, who drew attention to her being called "the most contemporary of the female writers", points out that appraising M.Drabble's creative period covering the 1960s and characterizing her works "A Summer Bird-Cage" (1963), "The Garrick Year" (1964), "The Millstone" (1965) written in that period as "the novels written by a young woman about young women", a number of researchers included the author into the range of "the representatives of feminist prose", while another group of researchers emphasized the development of her works in agreement with the development and establishment tendencies of the XX-century common English novel, referring to M.Drabble's works of the latest period (Spitzer 1978, p.78).

It is interesting that the woman's role in society, her choice or rather the problem of the lack of her choice at many points attracted M.Drabble much earlier than the period when feminist movement involved mass adherents. In this sense, one can state with certainty that M.Drabble is one of the leading XX-century feminist novelists-ideologists who raised the problem related to women's stands in society in the format of a tender British irony peculiar to her, yet quite austerely. M.Drabble herself states in this connection, "When I started writing there was no women's movement; there was no feminist criticism. Feminist criticism was born in 1968 precisely, and I published my first novel in 1963. So I was able to write in the innocent prefeminist theory days when no one was going to get at me for writing a sort of a feminine book or writing about marriage or clothes. Nobody. There was no prototype feminist novel at all, which made life easier. I had to take feminist attitudes and criticism on board in the 1970s. Then the issue of cultural appropriation came in very, very strongly in the 1990s". It was in her early works that she gave the interpretation of the free ideas such as giving birth to a child out of wed-lock and consciously refusing to get married which were challenges even for the British society then.

It is suffice to consider M.Drabble's novel "The Millstone", one of her earliest works in order to follow the exceptional role of this mature and consistent glorifier of the feminist ideas and her works unparalleled and ultimately courageous for her period in the contemporary British woman's enjoying more advantageous rights and freedoms. The writer, who describes (without exaggeration, almost) revolutionary changes in the life of a woman, in fact, a young virgin in the example of Rosamund Stacey, the main character of the novel "The Millstone" published in 1965, chooses her, and her wholeness, her future at the moment of a challenging decision and thus, decides on her child, her life and future by making a choice of becoming a mother in parallel. This choice, which might seem simplified in the present reality, was appraised as a kind of challenge to society by a Cambridge graduate and PhD researcher molded in the academic environment of the University of the 1960s. And when Rosamund, who being pregnant to an illegitimate child decided to give birth to her and grow her up, encountered her daughter's father after long years, it was Rosamund's choice not to tell him about his being the father of her daughter and Octavia's being their child.

T.Hadley, who points out, "Rosamund's adventure is pregnancy and motherhood, and her freedom is the option, new and still tentative in the 1960s, to become a single parent without stigma", is right to add further, "The novel is a paean for motherhood, yet it isn't sentimental 
or ecstatic; it's contained, most of the time, inside Rosamund's dry, knowing, deprecating language. That's one of the ways the book is radical: writing about motherhood, it turns out, needn't mean breaking with the language you used before, or with being clever".

The coincidence of the work with the period of "sexual revolution" facilitates understanding of the ideological background of the sharp metamorphosis of Drabble's heroine, that is, her demonstration of the courage to enter into relations out of wedlock while being virgin at her age of maturity and giving birth to a child out of these relations.

S.A.Diyaie and A.A.Taher, who point out, "The sexual revolution in the 1960s marked the landmark in women's lives and sexuality, consequently the majority of women wanted to express their sexuality freely", also state referring to the analysis of the development of the plot of the novel "Millstone", "Drabble criticizes the idea that women can attain respectability through men's existence in her life as proposed by this patriarchal world in which she lives. Undoubtedly, Drabble has a special competence to write about the experience of motherhood. The interaction between mother and child is for Drabble the most beautiful relationship in the world bringing her, "the greatest joy in the world' (Wolitzer 2013, p. 94). Indeed, Drabble's heroine demonstrates her freedom of choice, going against the rules of the patriarchal society and molded gender stereotypes. Actually, in this path to freedom Rosamund, who has suffered the moral compulsion and psychological tension of long years, obtains the comfort of escaping that burden (no matter how much this choice costs her), restores her moral identity compressed and deformed by patriarchal molds, turns to be herself.

\section{DISCUSSIONS}

According to Joyce Carol Oates, M.Drabble, in whose works "seemingly infinite sympathy for 'ordinary women'" plays a special part, admits that the relations between men and women, the problem of the woman's stand in society underwent no fundamental changes in many cases in the period when her first writing experience appeared. The writer elucidates her idea in this regard as follows, "....it is as though nothing has improved over 30 years. Men and women are still fighting for precedence and knocking into one another and thoroughly annoying each other in the same way they always have." (Drabble 1977, 2). No doubt, while the woman's role in the British society and her stand in the hierachy of intrasocietal relations have considerably changed for better since the appearance of M.Drabble's first feminism-spirited work, the writer is right at many points in the statements she articulates, which is not definitely associated with some national community, state, but is the state related to the gender stereotypes to be estimated in the regretful range of universality. Hence, M.Drabble emphasizes that marriage is, first of all, a social institution that goes against the rights of a woman rather than a man and can restrict her freedoms of development. M.Drabble's heroines radically disagree with the stereotypes of "women's duties" that confine them to the house, family, kitchen. As M.Drabble herself admits, "my women were interested in other things... their own lives and calling and politics and what they could give to life" (Perović 2015, p.18).

The analysis of M.Drabble's novel "Millstone" brings to the reader's judgement most austerely and boldly two confrontations peculiar to her works. Here the point is the confrontations of the woman's two hypostases - motherhood and spousehood which almost make "the neat line" of Drabble's novels. As rightly mentioned also by A.Y.Klimovskaya, who has studied the feminist ideas in M.Drabble and A.S.Byatt's works in comparison, although there are quite individual aspects, unparalelled peculiarities in both the sisters' works, one cannot but notice one common model, to be more precise, the moment of "the typological reciprocity of the gender problematics" in their approaches to the gender issue. The researcher, who emphasizes their 
heroines' confrontation with the social stereotypes dominating in relation to the woman's role within the family and motherhood, is right to state, "Both Byatt and Drabble treat marriage critically as a social institution restricting the woman's individuality, their emancipated heroines do not want confine themselves to realization as a woman, but also strive for the internal freedom and discovery of their own individuality" (Drabble 1977, 3). In other words, like both her sister and colleague A.S.Byatt, in her works M.Drabble can fully express her protest against the realization of a woman's choice in society, actually in the absence of choice dictated by the family institution. To be more precise, when defining the role ascribed to women by social stereotypes, the level of their active participation in the life of society, M.Drabble expresses in her statements through her heroines' voices that the woman's freedom of personality is "strangled" and discloses her protest against it. M.Drabble, who openly introduces herself as a feminist in her interviews, has a definite stand to the changing tendencies in the struggle for women's rights and in the approach towards women's freedom of choice, "Emancipation has taught a more robust attitude, thank goodness, but it is a freedom that has to be protected, for there are those around who are eager to push women back into the dark ages of suspicion and fear, and some of them call themselves feminists" (Tapaswi 2004, p.20).

As it is also rightly noted by A.Ismayilova, who emphasizes M.Drabble's almost all heroines' protest against Victorian morality and ethics in her early works, the very attitude of those heroines to the processes of changes taking place in the society of the 1960s is contradicting which manifests itself in the dual nature of those heroines. Despite their mental pertubation, they strive to adjust themselves more or less to the norms dominating in society. For instance, Rosamund (the main character of the novel "The Millstone - A.Sh.) tries to convince the people around her that she has several boyfriends at the same time, while, she, in fact, treats sex with a Victorian disgust" (Ismailova 2015, p.21). And, indeed, it becomes obvious from Rosamund's narration that due to her attitude of unusual inadmissibility towards the physical side of malefemale relations, she has decided to demonstrate quite an opposite attitude in order not to become the object of reproach or mockery and manages to leave an impression of dating with two young men Roger Herderson and Joe Hurt in parallel. In fact, as admitted also by Rosamund herself, this "romantic idyll" scheme carried on successfully for about a year is completely devastated as a result of her meeting her genuine love. Rosamund's meeting and familiarization with George Matthews brings her closer to the reality she tries to avoid. "My system worked well for about a year, and while it lasted it was most satisfactory; I look back on it now as on some distant romantic idyll. What happened was this. I went out with two people at once, one Joe Hurt, the other was Roger Anderson" (Drabble 1965, p.19).

In fact, according to her own acknowledgement, Rosamund who could easily fall in love and was fond of the very situation of falling in love, failed to overstep "the limits of bed" even with Hamish whom she considered her first love.

"When Hamish and I loved each other for a whole year without making love, I did not realize that I had set the mould of my whole year. One could find endless reasons for our abstinence fear, virtue, ignorance, perversion - but the fact remains that the Hamish pattern was to be endlessly repeated, and with increasing velocity and lack of depth, so that eventually the idea of love ended in me almost the day that it began" (Drabble 1965, p.7) .

Rosamund, who does not avoid self-analysis, defines her own "diagnosis" quite objectively in connection with this state, "Being at heart Victorian, I paid Victorian penalty. Luckily, I paid for 
the more shaming details in secret. Nobody ever knew quite how odd my sexual life was and nobody, not even the men I deluded, would have been prepared to entertain the idea of my virginity" (Drabble 1978, p.13). As it is obvious, the dualization of Rosamund's personality, her ambivalent attitude towards the sexual side of her love life as a woman are displayed here. While the stereotypes related to a woman's social dominance and her upbringing until the 1960s instill in Rosamund a progressive attitude towards the sexual life, the moment, when a mild attitude to the sexuality of love is being formed, makes that ambivalence in Rosamund unavoidable on the eve of the "sexual revolution, in the time span when society was pregnant to such serious, thriving changes. Rosamund is ashamed of her "Victorian chastity" in connection with that last moment (the start of the sexual revolution in the 1960s), openly fears that this state will be discovered by her close circle, that is, the bomond group organized by London's young intellectuals which consequently drives her into the game with a complicated scheme we have mentioned earlier.

Owing to George Matthews, who enters her life and with whom Rosamund falls in love for the first time as a woman, she escapes her "Victorian timidity". Moreover, she proves marriage to be not a decisive and vital point for a woman, by starting a fight for the equality of rights with an opposite sex. Rosamund vividly demonstrates that a woman also has her own dreams and desires related to her own realization with her choice of seclusion and that she has courage and power to follow those dreams. The dialogue at the last meeting with George Matthews about two years later displays Rosamund's decision - her making a choice of becoming a single mother despite the bitterness and sufferings she endevours through these years and her sufficient determination in her decision despite her some emotional hesitations. 'You never seemed to want a husband' 'No,' I said, 'perhaps I never did. Though I sometimes think it might be easier, to have one" (Drabble 1978, 171). Rosamund, who becomes definitely sure at this very meeting that no passion can prevail her love of motherhood, departs from George and makes her final decision to leave his life once and for all as if she has not tried hard her willpower to refrain herself from the emotional beatings of calling George and telling him the truth about little Octavia, the secret of her being George's daughter. "It was no longer in me to feel for anyone what I felt for my child; compared with the perplexed fitful illuminations of George, Octavia shone with a faint, constant and pearly brightness quite strong enough to eclipse any more garish future blaze. A bad investment, I knew, this affection, and one which would leave me in the dark and cold in years to come; but then what warmer passion ever lasted longer than six months?" (Drabble 1965, 198-199).

The statements expressed by M.Drabble's younger colleages approve vividly her successful management of the mission of a beacon showing the way in the hard painful metamorphoses a contemporary British woman, one can say without hesitation, a woman of the modern world has passed to recognize her real power and realize her psycho-social identity quite adequately. In this sense, as a generalized attitude, it would be appropriate to appraise the thoughts of Meg Wolitzer, one of the outstanding contemporary US woman writers, who highly appreciates M.Drabble's works. M.Drabble's young colleage evaluates her literary creativity and mission in society as follows, "Drabble's complex, psychological novels often dealt with the experience of being a young, sexually liberated woman. Love, infidelity, accidental pregnancy, intellectual awakening - all of it took place against a backdrop of 1960s and 1970s social change, particularly feminism. Her books made me feel like I was much more sophisticated than I really was; I loved them for what they taught me, and also for how cozy and familiar they felt".

\section{Literature}

1. Drabble M (1965). The Millstone. UK: Kindle Edition. 
2. Ismailova A. (2015). Women's Issues and the "generation gap" in the works of Afaq Masud and Margaret Drabble.Baku: AZ. Publishing.

3. John Mullan (2011). The Millstone by Margaret Drabble. UK:The Guardian.

4. Jane Flax (2005). Gender Equality. USA: New Dictionary of the History of Ideas.

5. Meg Wolitzer (2013). Margaret Drabble Spins A Mother-Daughter Yarn Into 'Gold'. New York: New York Publishing House.

6. Phyllis Rose (2004). Our Chronicler of Britain. UK: The New York Times.

7. Suhasini Tapaswi (2004). Feminine Sensibility in the Novels of Margaret Drabble: An Interpretation and Evaluation. India: Atlantic Publishers \& Distributors Pvt Ltd.

8. Sabah Atalla Diyaie, Jamila Abdul Amir Taher (2015). Woman's Quest for Survival: Margret Drabble's The Millstone. Iraq: Unversity of Baghdad. College Of Education For Women vol. 26 (4), 1185-1194.

9. Susan Spitzer (1978). Fantasy and Feminism in Margaret Drabble's The Millstone. Novel: A Forum on Fiction, Vol. 11, No.3, pp.227-245.

10. The Believer (2015). Margaret Drabble interviewed by Lydia Perović. France: Paris Rewier. 